TITLE:

\title{
Electrodeposition of bright Al-Zr alloy coatings from dimethylsulfone-based baths
}

\author{
$\operatorname{AUTHOR}(S)$ :
}

Shiomi, Suguru; Miyake, Masao; Hirato, Tetsuji

\section{CITATION:}

Shiomi, Suguru ... [et al]. Electrodeposition of bright Al-Zr alloy coatings from dimethylsulfone-based baths. Journal of the Electrochemical Society 2012, 159(4): D225D229

ISSUE DATE:

2012-02-01

URL:

http://hdl.handle.net/2433/237619

\section{RIGHT:}

(c) The Electrochemical Society, Inc. 2012. All rights reserved. Except as provided under U.S. copyright law, this work may not be reproduced, resold, distributed, or modified without the express permission of The Electrochemical Society (ECS). The archival version of this work was published in 'J. Electrochem. Soc. 2012 volume 159, issue 4, D225-D229'; 二 の論文は出版社版でありません。引用の際には出版社版をご確認じ利用ください。; This is not the published version Please cite only the published version. 


\section{Electrodeposition of bright Al-Zr alloy coatings from dimethylsulfone-based baths}

Suguru Shiomi, Masao Miyake, and Tetsuji Hirato

Graduate School of Energy Science, Kyoto University

Yoshida-hommachi, Sakyo-ku, Kyoto 606-8501, Japan

*Address correspondence to: Prof. T. Hirato

hirato.tetsuji.2n@kyoto-u.ac.jp

+81-75-753-5432

\section{Abstract}

Electrodeposition of $\mathrm{Al}$ coatings from dimethylsulfone $\left(\mathrm{DMSO}_{2}\right)-\mathrm{AlCl}_{3}$ baths with the addition of $\mathrm{ZrCl}_{4}$ was studied. Although pure $\mathrm{Al}$ coatings electrodeposited from the bath without $\mathrm{ZrCl}_{4}$ are lusterless, bright and smooth coatings were obtained when the $\mathrm{ZrCl}_{4}$ content in the baths was $0.005-0.015$ mol per 10 mol $\mathrm{DMSO}_{2}$. The $\mathrm{Zr}$ content in the coatings varied up to 3.5 at\% in proportion to the $\mathrm{ZrCl}_{4}$ content in the baths. The bright $\mathrm{Al}-\mathrm{Zr}$ alloy coating showed high reflectance of $50-80 \%$ in the wavelength range of $450-1000 \mathrm{~nm}$, whereas that of the matte pure $\mathrm{Al}$ coating was $10-20 \%$. Morphological observations confirmed a reduction in the grain size of $\mathrm{Al}$ and surface leveling caused by the addition of $\mathrm{ZrCl}_{4}$ to the baths. Moreover, a strong $<100>$ preferential orientation of Al crystals was observed for the bright coatings. The bright coating containing 3.5 at $\% \mathrm{Zr}$ had a higher corrosion potential by $0.1 \mathrm{~V}$ than the pure $\mathrm{Al}$ coating.

Keywords: electroplating, aluminum alloy, organic solvent 
Aluminum offers good corrosion resistance owing to the natural oxide layer formed on its surface and thus can be used as a corrosion-resistant coating for metallic materials. In general, electrodeposition is the preferred method for the fabrication of such coatings because it is simple and cost-effective compared to other common processes such as hot dipping, ${ }^{1}$ thermal spraying ${ }^{2}$ and chemical vapor deposition. ${ }^{3}$ Moreover, electrodeposition has merits that complex-shaped components can be coated and the thickness of the coatings can be easily controlled.

However, it is well known that metallic Al cannot be electrodeposited from commonly-used aqueous solutions, and hence a number of non-aqueous media including aromatic hydrocarbons, ${ }^{4}$ etheric solvents ${ }^{4}$ and inorganic molten salts ${ }^{5}$ have been studied to date. However, they have some drawbacks such as combustibility, high vapor pressure and dendritic growth of deposit. In recent years, ionic liquids, also known as room temperature molten salts, have been extensively explored for the electrodeposition of pure $\mathrm{Al}$ as well as $\mathrm{Al}$ alloys. ${ }^{6-12}$ The ionic liquids are attractive media since they have low vapor pressure, high electrical conductivity and a wide electrochemical window. ${ }^{6}$ Dimethylsulfone $\left(\mathrm{DMSO}_{2}\right)-\mathrm{AlCl}_{3}$ electrolyte is also an attractive medium for the electrodeposition of Al because it is more stable and therefore easier to handle than the conventional media. In this electrolyte, $\mathrm{AlCl}_{3}$ undegoes a solvolysis reaction and forms two soluble species, $\mathrm{AlCl}_{4}{ }^{-}$and $\mathrm{Al}\left(\mathrm{DMSO}_{2}\right)_{3}{ }^{3+}$ and electrodeposition of $\mathrm{Al}$ occurs from the $\mathrm{Al}\left(\mathrm{DMSO}_{2}\right)_{3}{ }^{3+}{ }^{+}$complex. ${ }^{17}$ Smooth, dense $\mathrm{Al}$ coatings are reportedly obtained from $\mathrm{DMSO}_{2}-\mathrm{AlCl}_{3}$ baths. ${ }^{13-16,18-20}$

Although electrodeposition of $\mathrm{Al}-\mathrm{Ti},{ }^{9,10} \mathrm{Al}-\mathrm{Mo},{ }^{11} \mathrm{Al}-\mathrm{Zr}^{12}$ alloys has been studied in ionic liquid systems, electrodeposition of $\mathrm{Al}$ alloys from the $\mathrm{DMSO}_{2}$ system has not been studied extensively. To the best of our knowledge, the attempted electrodeposition 
of Al-Ti alloy by Legrand and co-workers is the only report on electrodeposition of $\mathrm{Al}$ alloys from $\mathrm{DMSO}_{2}$ based baths available in the literature. ${ }^{21,22}$ Thus, little is known about the effects of secondary metal-elements on the electrodeposition of $\mathrm{Al}$ from the $\mathrm{DMSO}_{2}-\mathrm{AlCl}_{3}$ electrolytes.

In this paper, we focus on $\mathrm{Zr}$, which is one of the elements known to improve the corrosion resistance of $\mathrm{Al} .^{23,24}$ Our preliminary experiments confirmed that $\mathrm{Zr}$ can be co-deposited with $\mathrm{Al}$ from a $\mathrm{DMSO}_{2}$ based bath containing $\mathrm{ZrCl}_{4}$. Furthermore, we found that the brightness of the electrodeposited coatings was drastically enhanced by the addition of $\mathrm{ZrCl}_{4}$. The electrodeposition of bright $\mathrm{Al}$ coatings from the $\mathrm{DMSO}_{2}$ system has not been reported so far, although it has been studied in ionic liquid systems. ${ }^{25}$ In the present study, the effect of $\mathrm{ZrCl}_{4}$ addition to $\mathrm{DMSO}_{2}$ baths on the brightness, surface morphologies and corrosion resistance of electrodeposited coatings was examined in detail.

\section{Experimental}

\section{Electrodeposition}

Copper plates $(1.5 \mathrm{~cm} \times 3.0 \mathrm{~cm})$ were used as substrates for the electrodeposition of $\mathrm{Al}$ and $\mathrm{Al}-\mathrm{Zr}$ alloys. Prior to the electrodeposition, the substrates were polished with a SiC paper, and then cleaned by sonication in ethanol. After the cleaning, a part of each substrate was covered with PTFE tape so that a square area (1 $\mathrm{cm} \times 1 \mathrm{~cm})$ would be exposed. The anode was an aluminum plate $(2.5 \mathrm{~cm} \times 3 \mathrm{~cm})$, which was polished and rinsed in water and ethanol before the electrodeposition. The Al plate works as a sacrificial anode to maintain the concentration of $\mathrm{Al}$ species in the 
bath. $^{13}$

The plating bath was prepared by mixing $\mathrm{DMSO}_{2}$ (Tokyo Chemical Industry, $>99.0 \%$ ) and $\mathrm{AlCl}_{3}$ (Fluka, anhydrous $\geq 99.0 \%$ ) at a mol ratio of $10: 2$, and then $\mathrm{ZrCl}_{4}$ (Wako Pure Chemical) was added to the bath. The $\mathrm{ZrCl}_{4}$ content in the bath was varied from 0 mol to 0.015 mol per 10 mol $\mathrm{DMSO}_{2}$ (All the values of $\mathrm{ZrCl}_{4}$ content in this paper describe the amount of $\mathrm{ZrCl}_{4}$ per 10 mol $\mathrm{DMSO}_{2}$ ). Prior to use, $\mathrm{DMSO}_{2}$ had been dried in a vacuum at $60{ }^{\circ} \mathrm{C}$ for more than one day. No further purification was conducted. $\mathrm{AlCl}_{3}$ and $\mathrm{ZrCl}_{4}$ were stored in an Ar-filled glove box with a circulation system and used as received. After mixing, they were melted at $110{ }^{\circ} \mathrm{C}$.

A conventional two-electrode cell was employed for the electrodeposition. Al-Zr alloys were electrodeposited at constant current density of $60 \mathrm{~mA} \mathrm{~cm}^{-2}$ for $10 \mathrm{~min}$ using an electrochemical analyzer (ALS, model 660C). Assuming 100\% current efficiency, an Al layer with a thickness of about $12 \mu \mathrm{m}$ was obtained under the deposition conditions. During the electrodeposition, the bath was stirred at $400 \mathrm{rpm}$ and the temperature of the bath was kept at $110{ }^{\circ} \mathrm{C}$ with a thermostat. The preparation of the baths and the electrodeposition were carried out in the Ar-filled glove box.

\section{Characterization}

Normal-incidence specular reflectance spectra for the electrodeposited coatings were measured using a multichannel photodetector (Otsuka electronics, MCPD-7700) coupled with an optical microscope (Nikon, Eclipse LV100). Spectra were taken from a $20 \mu \mathrm{m}$ diameter spot using a 10x objective lens with a numerical aperture of 0.3 with reference to an $\mathrm{Al}$ mirror with a $50 \mathrm{~nm} \mathrm{MgF} 2$ coating (Sigma Koki Co., Ltd., TFA25C05-20). The measured data were converted to absolute reflectance with the use of 
the simulated reflectance spectrum for the mirror. The composition of the coatings was detemined by EDX coupled with an SEM (Hitachi S-3500). XRD patterns were taken by employing a diffractometer (Panalytical, X'Pert PRO-MPD) with $\mathrm{Cu}-\mathrm{K} \alpha$ radiation. An FE-SEM (Hitachi, SU6600) was used to observe the surface morphology of the coatings. The roughness was measured by a surface texture measuring instrument (Surfcom 1400D, Tokyo Seimitsu). The parameters for the measurement were cutoff length of $0.8 \mathrm{~mm}$, and cutoff ratio of 300 . The scanned length was $3.0 \mathrm{~mm}$ and the scan rate was $0.15 \mathrm{~mm} \mathrm{~s}^{-1}$. The roughness was calculated based on ISO '97. The corrosion resistance of the coatings was evaluated by recording potentiodynamic anodic polarization curves in deaerated $0.1 \mathrm{M} \mathrm{NaCl}$ solution at ambient temperature, using a potentiostat (Hokuto Denko, HZ-5000) at a scan rate of $0.5 \mathrm{mV} \mathrm{s}^{-1}$. The conventional three-electrode cell was employed for the measurement. The measurement was performed for a circular area with a diameter of $5.8 \mathrm{~mm}$ on the surface of the coatings. A Pt coil was used as the counter electrode and an Ag/AgCl electrode (SSE) in a $\mathrm{KCl}$ saturated aqueous solution was used as the reference electrode.

\section{Results and Discussion}

The electrodeposition of $\mathrm{Al}$ from the $\mathrm{DMSO}_{2}-\mathrm{AlCl}_{3}$ bath without any additives produces dense, uniform pure $\mathrm{Al}$ coatings, but the coatings are lusterless. In contrast, a bright coating was electrodeposited when $0.01 \mathrm{~mol} \mathrm{ZrCl}_{4}$ was added to the plating bath. Figure 1 presents photographs comparing the appearance of the coatings electrodeposited from baths without and with $0.01 \mathrm{~mol} \mathrm{ZrCl}_{4}$. Whereas the coating obtained in the absence of $\mathrm{ZrCl}_{4}$ is dull-white, that from the $\mathrm{ZrCl}_{4}$-containing bath has a silvery, mirror-like appearance. Normal-incidence reflectance spectra for these coatings 
show more quantitatively that the coating obtained with incorporation of $\mathrm{ZrCl}_{4}$ has a bright, reflective surface (Figure 2). The reflectance of the matte Al coating without $\mathrm{ZrCl}_{4}$ is as small as $10-20 \%$ over the visible and near-infrared region $(450-1000 \mathrm{~nm})$. As for the bright coating, even the minimum reflectance is as high as $50 \%$ at $450 \mathrm{~nm}$. The reflectance increases at longer wavelengths and approaches $80 \%$ in the near-infrared region (800-1000 nm), showing that the bright coating from the $\mathrm{ZrCl}_{4}$-containing bath has over 4-times higher reflectance than the pure $\mathrm{Al}$ coating.

In order to examine the effect of $\mathrm{ZrCl}_{4}$ in more detail, electrodeposition was conducted from $\mathrm{DMSO}_{2}-\mathrm{AlCl}_{3}$ baths containing various amounts of $\mathrm{ZrCl}_{4}$ at a constant current density of $60 \mathrm{~mA} \mathrm{~cm}{ }^{-2}$. When the $\mathrm{ZrCl}_{4}$ content was less than $0.005 \mathrm{~mol}$, the electrodeposited coatings were matte. Bright coatings were obtained from the baths with $\mathrm{ZrCl}_{4}$ contents from 0.005 to 0.015 mol. When the $\mathrm{ZrCl}_{4}$ content was higher than 0.015 mol, the color of the coatings turned to dark, and adhesion of the coatings degraded. Such coatings are not suitable for corrosion protection and thus we did not carry out further characterization for the dark coatings.

The relationship between the $\mathrm{ZrCl}_{4}$ content in the plating baths and $\mathrm{Zr}$ content in the coatings is shown in Figure 3. The amount of $\mathrm{Zr}$ in the coatings varied from 0 at $\%$ to 3.5 at\% in proportion to the $\mathrm{ZrCl}_{4}$ content in the plating bath, suggesting that the deposition of $\mathrm{Zr}$ is diffusion-controlled. The bright coatings contained 1.2-3.5 at\% Zr. The EDX analysis also revealed that the coatings contained $0.2 \sim 1.4$ at $\%$ of $\mathrm{Cl}$ and $\mathrm{S}$ as impurities.

The coatings were also examined by XRD (Figure 4). Diffraction peaks corresponding to $\mathrm{Al}$ and $\mathrm{Cu}$ substrates were confirmed for all the samples. Although the 
Zr content of the Al-Zr alloy coatings (0.5-3.5 at\% Zr) exceeded the maximum solubility of $\mathrm{Zr}$ in $\mathrm{Al}$ phase $(<0.1$ at\%), no evidence for the formation of $\mathrm{Al}-\mathrm{Zr}$ intermetallics or metallic $\mathrm{Zr}$ was found in the XRD patterns. If $\mathrm{Zr}$ is dissolved in the $\mathrm{Al}$ phase to form an oversaturated solid-solution, corresponding peak shift should be observed in the XRD pattern of the Al phase. However, no peak shift was observed. This is possibly because most of the $\mathrm{Zr}$ deposited is present separately from the $\mathrm{Al}$ phase. Secondary phase cannot be detected by XRD because the $\mathrm{Zr}$ amounts in the coatings are too small. The diffraction patterns of the pure $\mathrm{Al}$ (Figure $4 \mathrm{a}$ ) and the $\mathrm{Al}-\mathrm{Zr}$ alloy electrodeposited with the addition of $0.0025 \mathrm{~mol} \mathrm{ZrCl}_{4}$ (Figure $4 \mathrm{~b}$ ), which exhibit a matte appearance, are similar to that of an $\mathrm{Al}$ powder, indicating that the coatings are composed of randomly orientated $\mathrm{Al}$ crystal grains. The diffraction pattern significantly changes when the $\mathrm{ZrCl}_{4}$ content in the bath is raised to $0.005 \mathrm{~mol}$; the intensity of $\mathrm{Al}$ 200 diffraction becomes about 40 times greater than that for the pure $\mathrm{Al}$ coating (Figure $4 \mathrm{c}$ ), while the intensity of $\mathrm{Al} 111$ diffraction remains as low as that for the pure $\mathrm{Al}$ coating. The strong Al 200 diffraction clearly shows that the Al-Zr alloy coating obtained with $0.005 \mathrm{~mol} \mathrm{ZrCl}_{4}$ has a preferrential orientation where (100) planes are parallel to the substrate. Similar XRD patterns are observed for the coatings obtained from the baths containing 0.01 and $0.015 \mathrm{~mol} \mathrm{ZrCl}_{4}$ (Figure $4 \mathrm{~d}$ and e) except that the Al 111 diffraction completely disappears and the $\mathrm{Al} 200$ diffraction becomes more intense. This set of XRD patterns indicates that the $\mathrm{Al}$ crystals in the bright coatings have a strong $<100>$ preferrential orientation, while those in the matte coatings have no preferred orientation.

Figure 5 presents SEM images showing typical surface morphologies of the coatings. Randomly-scattered angular grains of Al approximately $5 \mu \mathrm{m}$ in size can be 
seen on the surface of the pure $\mathrm{Al}$ coating (Figure $5 \mathrm{a}$ ). A similar morphology, except with the grain size decreased to around $1 \mu \mathrm{m}$, can be found on the sample obtained from the bath containing $0.0025 \mathrm{~mol} \mathrm{ZrCl}_{4}$ (Figure $5 \mathrm{~b}$ ). In contrast, the grain size of the bright coatings obtained by the addition of of $0.005-0.015 \mathrm{~mol} \mathrm{ZrCl}_{4}$ diminished to approximately $20 \mathrm{~nm}$ (Figure $5 \mathrm{c}$-e). As a result, the surfaces of these coatings became smoother than that of the matte pure Al coating. Although the SEM images of the surface of the bright coatings indicated the drastic decrease in the grain size, the XRD peak of the bright coatings was not broadened. This suggests that the bright coatings consist of thin columnar grains grown perpendicularly to the substrate.

The smooth surface of the coatings was also evidenced by roughness measurement (Figure 6). The mean roughness $(\mathrm{Ra})$ of the matte pure $\mathrm{Al}$ coating was approximately $0.1 \mu \mathrm{m}$. The roughness of the coating did not change when $0.0025 \mathrm{~mol}$ $\mathrm{ZrCl}_{4}$ was added to the plating bath, whereas the Ra dramatically decreased to $0.01 \mu \mathrm{m}$ when $0.005 \mathrm{~mol}$ or more $\mathrm{ZrCl}_{4}$ was added to the bath. The maximum height $(\mathrm{Rz})$ varied similarly to Ra and was $1.2-1.7 \mu \mathrm{m}$ and $0.3 \mu \mathrm{m}$ for the matte coatings and bright coatings, respectively (Figure $6 \mathrm{~b}$ ). The variations in the surface roughness are in agreement with the surface morphologies of the coatings revealed by the SEM images (Figure 5). The Ra and $\mathrm{Rz}$ for the bright coatings obtained in this study are much smaller than the reported values for the bright $\mathrm{Al}$ coatings electrodeposited from an ionic liquid bath containing 1,10-phenantroline as a brightener $(\mathrm{Ra}=0.12 \mu \mathrm{m}, \mathrm{Rz}=1.0$ $\mu \mathrm{m}),{ }^{25}$ thus showing the better brightening ability of $\mathrm{ZrCl}_{4}$ in the $\mathrm{DMSO}_{2}$ based bath.

The SEM images (Figure 5) and the XRD patterns (Figure 4) show that the grain size and the crystal orientation simultaneously undergo significant changes when 0.005 
mol or more $\mathrm{ZrCl}_{4}$ is added to the bath. The grain refinement and preferential crystal orientation are typical phenomena in bright coatings electrodeposited with the aid of brighteners. ${ }^{26}$ Additionaly, we carried out cyclic voltammetry in the $\mathrm{DMSO}_{2}-\mathrm{AlCl}_{3}$ electrolyte with and without $\mathrm{ZrCl}_{4}$ and confirmed that the reduction current is suppressed when $\mathrm{ZrCl}_{4}$ is present in the electrolyte. For these reasons, we presume that $\mathrm{ZrCl}_{4}$ produces bright coatings by a similar mechanism to the commonly-used brighteners. The proposed mechanism is as follows: $\operatorname{Zr}(\mathrm{IV})$ species in a plating bath are preferentially adsorbed onto peaks of Al deposit and particular crystal planes. The adsorbed species suppress the crystal growth of $\mathrm{Al}$ in particular crystal directions at the peaks of deposit, leading to the production of preferentially oriented fine crystal grains and a leveled surface with small irregularities. The resulting surface with smaller irregularities than the wavelength of the visible light looks bright and lustrous, because light incident to the surface is reflected without being diffused.

$\mathrm{Al}-\mathrm{Zr}$ alloys prepared by the electrodeposition from $\mathrm{AlCl}_{3}$-1-ethyl-3methylimidazolium chloride ionic liquid are reported to have superior corrosion resistance to that of pure $\mathrm{Al} .{ }^{12}$ In order to examine whether the corrosion resistance of the $\mathrm{Al}-\mathrm{Zr}$ alloy coatings obtained from the $\mathrm{DMSO}_{2}$ bath is also improved, the corrosion resistance of the pure $\mathrm{Al}$ and the $\mathrm{Al}-3.5 \% \mathrm{Zr}$ alloy coatings electrodeposited from a $\mathrm{DMSO}_{2}$ bath containing $0.015 \mathrm{~mol} \mathrm{ZrCl}_{4}$ was compared by potentiodynamic anodic polarization in a $\mathrm{NaCl}$ aqueous solution (Figure 7). The passive region of the pure $\mathrm{Al}$ coating lies below $-0.6 \mathrm{~V}$ vs. SSE followed by a sudden rise in anodic current. The rise in the anodic current is explained by pitting corrosion of $\mathrm{Al}$ induced by chloride ions. ${ }^{23,24}$ The curve for the Al-Zr alloy displays a wider passive region up to $-0.5 \mathrm{~V}$ vs. SSE, indicating that the addition of $\mathrm{Zr}$ to $\mathrm{Al}$ by the electrodeposition from the $\mathrm{DMSO}_{2}$ 
bath is effective for the enhancement of the corrosion resistance of Al.The shift in the corrosion potential of $0.1 \mathrm{~V}$ is comparable to those for the $\mathrm{Al}-\mathrm{Zr}$ alloys electrodeposited from the ionic liquid bath. ${ }^{12}$

\section{Conclusion}

In this paper, we presented the electrodeposition of Al-Zr alloy coatings from $\mathrm{DMSO}_{2}$-based baths. Al-Zr alloy coatings containing up to 3.5 at $\% \mathrm{Zr}$ were obtained in the presence of $\mathrm{ZrCl}_{4}$ in the baths. The addition of $\mathrm{ZrCl}_{4}$ had the effects of grain

refining and surface leveling, resulting in the formation of bright coatings with a silvery, mirror like appearance. The bright Al-Zr alloy coating showed high reflectance of 50$80 \%$ in the visible and near-infrared region. Moreover, the addition of $\mathrm{Zr}$ to the coating from the $\mathrm{DMSO}_{2}$ bath was confirmed to be effective for the enhancement of corrosion resistance. These results expand the potential applications of electrodeposited $\mathrm{Al}-\mathrm{Zr}$ coatings to decorative coatings and coatings for optical devices as well as corrosion resistant coatings.

\section{Acknowledgement}

The authors thank Kenji Kazumi and Teruyoshi Unesaki for their assistance in SEM observation. 


\section{References}

1. W.-J. Cheng and C.-J. Wang, Surf. Coat. Tech., 205, 4726 (2011).

2. M. Campo, M. Carboneras, M. D. López, B. Torres, P. Rodrigo, E. Otero and J. Rams, Surf. Coat. Tech., 203, 3224 (2009).

3. Y. Liu, L. J. Overzet and M. J. Goeckner, Thin Solid Films, 510, 48 (2006).

4. M. Gálová, Surf. Technol., 11, 357 (1980).

5. L. Qingfeng, H. A. Hjuler, R. W. Berg and N. J. Bjerrum, J. Electrochem. Soc., 137, 593 (1990).

6. T. Jiang, M. J. C. Brym, G. Dubé, A. Lasia and G. M. Brisard, Surf. Coat. Tech., 201, 1 (2006).

7. Q. X. Liu, S. Z. E. Abedin and F. Endres, Surf. Coat. Tech., 201, 1352 (2006).

8. H. C. De Long, J. Fuller and P. C. Trulove, J. Electrochem. Soc., 145, 1598 (1998).

9. T. Tsuda, C. L. Hussey, G. R. Stafford and J. E. Bonevich, J. Electrochem. Soc., 150, C234 (2003).

10. D. Pradhan, R. G. Reddy and A. Lahiri, Metall. Mater. Tans. B, 40B, 114 (2009).

11. T. Tsuda, C. L. Hussey and G. R. Stafford, J. Electrochem. Soc., 151, C379 (2004).

12. T. Tsuda, C. L. Hussey, G. R. Stafford and O. Kongstein, J. Electrochem. Soc., 151, C447 (2004).

13. L. Legrand, A. Tranchant and R. Messina, Electrochim. Acta, 39, 1427 (1994).

14. L. Legrand, A. Tranchant and R. Messina, J. Electrochemi. Soc., 141, 378 (1994).

15. L. Legrand, M. Heintz, A. Tranchant and R. Messina, Electrochim. Acta, 40, 1711 (1995).

16. L. Legrand, A. Tranchant and R. Messina, Electrochim. Acta, 41, 2715 (1996).

17. L. Legrand, A. Tranchant, R. Messina, F. Romain and A. Lautie, Inorg. Chem., 35, 
1310 (1996).

18. T. Hirato, J. Fransaer and J.-P. Celis, J. Electrochem. Soc., 148, C280 (2001).

19. J. Fransaer, E. Leunis, T. Hirato and J-P. Celis, J. Appl. Electrochem., 32, 123 (2002).

20. T. Jiang, M. J. C. Brym, G. Dubé, A. Lasia and G. M. Brisard, Surf. Coat. Tech., 201,6309 (2007).

21. L. Legrand, A. Chaussé and R. Messina, J. Electrochem. Soc., 145, 110 (1998).

22. L. Legrand, A. Chausse and R. Messina, Electrochim. Acta, 46, 2407 (2001).

23. G. D. Davis, W. C. Moshier, T. L. Frits and G. O. Cote, J. Electrochem. Soc., 137, $422(1990)$.

24. Z. Szklarska-Smialowska, Corros. Sci., 41, 1743 (1999).

25. L. Barchi, U. Bardi, S. Caporali, M. Fantini, Alessandro Scrivani and Andrea Scrivani, Prog. Org. Coat., 67, 146 (2010).

26. L. Oniciu and L. Mureşan, J. Appl. Electrochem., 21, 565 (1991). 


\section{Figure Captions}

Figure 1 Photographs of (a) matte $\mathrm{Al}$ coating and (b) bright Al-Zr coating electrodeposited on $\mathrm{Cu}$ substrates from $\mathrm{DMSO}_{2}-\mathrm{AlCl}_{3}$ bath containing no and $0.01 \mathrm{~mol}$ $\mathrm{ZrCl}_{4}$, respectively.

Figure 2 Normal-incidence reflectance spectra of (a) matte Al coating and (b) bright Al$\mathrm{Zr}$ coating electrodeposited on $\mathrm{Cu}$ substrates from $\mathrm{DMSO}_{2}-\mathrm{AlCl}_{3}$ bath containing no and $0.01 \mathrm{~mol} \mathrm{ZrCl}_{4}$, respectively.

Figure 3 Relationship between $\mathrm{ZrCl}_{4}$ content in the plating bath and $\mathrm{Zr}$ content in electrodeposited coating.

Figure 4 XRD patterns of pure $\mathrm{Al}$ and $\mathrm{Al}-\mathrm{Zr}$ alloy coatings electrodeposited from $\mathrm{DMSO}_{2}$ based baths containing various amounts of $\mathrm{ZrCl}_{4}$ : (a) 0 mol (pure aluminum), (b) $0.0025 \mathrm{~mol}$, (c) $0.005 \mathrm{~mol}$, (d) $0.010 \mathrm{~mol}$, and (d) $0.015 \mathrm{~mol}$. Diffraction peaks of $\mathrm{Cu}$ substrate are denoted by

Figure 5 SEM images of the surfaces of pure $\mathrm{Al}$ and $\mathrm{Al}-\mathrm{Zr}$ alloy coatings electrodeposited from $\mathrm{DMSO}_{2}$ based baths containing various amounts of $\mathrm{ZrCl}_{4}$ : (a) 0 mol (pure aluminum), (b) $0.0025 \mathrm{~mol}$, (c) $0.005 \mathrm{~mol}$, (d) $0.010 \mathrm{~mol}$, and (d) $0.015 \mathrm{~mol}$. 
Figure 6 Surface roughness of coatings electrodeposited from $\mathrm{DMSO}_{2}-\mathrm{AlCl}_{3}$ baths as a function of $\mathrm{ZrCl}_{4}$ content in the bath: (a) arithmetical mean roughness (b) maximum roughness height (ISO '97).

Figure 7 Anodic polarization curves recorded in $0.1 \mathrm{M} \mathrm{NaCl}$ aqueous solution for (a) pure aluminum coating and (b) Al-3.5\% Zr alloy coating. The Al-3.5\% Zr alloy coating was obtained from a bath containing $0.015 \mathrm{~mol} \mathrm{ZrCl}_{4}$. 